\title{
Heterogeneous Nuclear Ribonucleoprotein A3
}

National Cancer Institute

\section{Source}

National Cancer Institute. Heterogeneous Nuclear Ribonucleoprotein A3. NCI Thesaurus. Code C26308.

Heterogeneous nuclear ribonucleoprotein $\mathrm{A} 3$ ( $378 \mathrm{aa}, \sim 40 \mathrm{kDa}$ ) is encoded by the human HNRNPA3 gene. This protein is involved in both RNA trafficking and splicing. 